\title{
The Influence of Educational Qualifications, Work Periods, and School Climate on the Performance of Economic Teachers in Vocational Schools in Makassar City
}

\author{
Muhammad Azis ${ }^{1}$, Anismawardani Bakri², Darman Manda ${ }^{3}$ \\ Universitas Negeri Makassar \\ Email: azis_feunm@yahoo.com
}

(Received: March 15-2019; revised: March 30-2019; published: May 31-2019)

\begin{abstract}
This study aims to determine the effect of educational qualifications, years of service, and school climate on the performance of economic teachers in SMKs throughout Makassar. The type of this research is Expo-Facto research with Population are all economic teachers of Vocational High Schools in Makassar City. The sampling technique uses a saturated sampling technique (census). Data collection techniques are questionnaires, observation and documentation. The results show that (1) There is a direct influence of educational qualifications on the school climate on the performance of economic teachers, (2) There is a significant positive direct effect on the working period on the school climate on economic teacher performance, (3) There is a significant direct influence on economic teacher performance, (4) There is a direct influence on the work period on the performance of economic teachers, (5) There is a direct influence of the school climate on the performance of economic teachers, (6) There is an indirect influence of education qualifications through the school climate on economic teacher performance (7) There is an indirect influence on the working period through the school climate on the performance of economic teachers.
\end{abstract}

Keywords: education qualification; years of service; school climate; performance of economic teachers

\section{INTRODUCTION}

The existence of a teacher is the main facilitator in the implementation of the learning process in school. The presence of professional teachers is very influential in realizing national education goals. In terms of educational activities in schools, it is appropriate if the teacher's role gets serious attention so that it can be known about the condition and quality of performance through the factors that influence it, so that appropriate policies can be taken to improve and develop it in line with the demands of change, implemented in schools can really lead right towards achieving the expected goals of improving the quality of education. Therefore, it is necessary to improve teacher performance.

Performance is the result of work in the quality and quantity achieved by an employee in carrying out his duties and responsibilities given to him (Akib \& Salam, 2016; Li \& He, 2019; Saad, Cleveland, \& Ho, 2015; Saggaf, Aras, et al., 2018; Saggaf \& Salam, 2017; Song, 2019; Sui, Smith, Fagan, Rollo, \& Prapavessis, 2019; Wargocki \& Wyon, 2017). Performance is the nature and characteristics of a job that is stated as a record of one's work, with the criteria of self-development, teamwork, communication, the number of products produced, and decisions

Copyright (C) 2019 Universitas Negeri Makassar. This is an open access article under the CC BY license (http://creativecommons.org/licenses/by/4.0/)

Number: (RISTEKDIKTI) 21/E/KPT/2018 
58 Jurnal Ilmiah Ilmu Administrasi Publik: Jurnal Pemikiran dan Penelitian Administrasi Publik Volume 9 Number 1, January - June 2019. Page 57-70

made, absent without permission and errors over a period of time. Performance is the end result of an activity that someone has done to achieve a goal. The achievement of this work is also a form of comparison of the results of one's work with the standards set. If the work done by someone is in accordance with work standards or even exceeds the standard, it can be said that the performance achieves good performance

Performance (job performance) is a record of results or outputs (outcomes) that are produced from a particular job function or certain activities in a certain period (Mahlamäki, Rintamäki, \& Rajah, 2018; Singh \& Singh, 2018). Performance is a result achieved by a person in carrying out his duties on skills, effort and opportunity. Based on the exposure, performance is a result achieved by someone in carrying out tasks based on skills, experience, and sincerity and time according to predetermined standards (Hasibuan, 2002).

In this study, performance is related to the existence of economic teachers as educators, related to learning planning. Performance factors are also influenced by motivation, job satisfaction, stress levels, physical conditions of work, compensation systems, job design, commitment to the organization and economic aspects and other behaviors (Primaraharjo \& Handoko, 2011).

Based on the results of a preliminary study conducted in several SMKs in Makassar, many teachers still have a Bachelor's (S1) education qualification and have not been motivated to continue their education. Some teachers also have difficulty teaching because they do not master the material and the relevance of the subject is not in accordance with the subjects that are effective. Some teachers who have had a long working period are less willing to socialize with other teachers, and look indifferent to young teachers. There are also some teachers who are less enthusiastic in school because the conditions of the school environment are not conducive, so to improve teacher performance, the influence of these factors needs to be optimized.

Several factors that can influence the performance of economic teachers include educational qualifications, years of service and school climate. One of the factors that influence the performance of economic teachers is educational qualifications. Educational qualifications are closely related to the performance of teachers in carrying out roles as agents of learning (learning agents) (Akib \& Salam, 2016; Dharma \& Akib, 2005; Hariyono et al., 2019; Khunsoonthornkit \& Panjakajornsak, 2018; Song, 2019). As learning agents teachers have a central and strategic role as facilitators, motivators, drivers, learning engineers, and learning inspirers for students. All this can be owned by the teacher when the concerned person always tries to improve his education qualifications. Academic qualification is the level of formal education that has been achieved by teachers both in degree education such as S1, S2 or S3. Qualifications as abilities or competencies that must be possessed by a teacher in carrying out his duties (Muslich, 2007).

Teacher's academic qualifications are listed in Government Regulation Number 19 of 2005 concerning National Education Standards, Chapter IV, first part, article 29, fourth item. The Government Regulation reads that educators have: (1) minimum diploma academic qualifications or undergraduate degree (S1); (2) higher education background with educational programs that are in accordance with the subjects taught; (3) teacher professional certification. 
The results of research conducted by Wahyuni concluded that there was a simultaneous influence between training education (DIKLAT) on the working period and work attitudes towards teacher performance at Tanete Bulukumba 410 MTs Negeri (Wahyuni, 2016). In addition to educational qualifications, in improving the performance of economic teachers there are also other factors that also affect the performance of economic teachers, namely the tenure of the teacher. According to The Liang Gie in Wahyuni (2016) Work period is the overall implementation of physical and spiritual activities carried out by humans to achieve their goals or contain a specific purpose.

Teachers who have a long working period will have a lot of experience both in educating and teaching, and experience in the work environment, with a lot of experience and senior teachers are expected to do their jobs better and can provide good examples. The teacher has sufficient work experience, the longer a teacher carries out his duties, the more experience he has. Teacher's work experience is in line with the tenure of the teacher, the more years of work the teacher has, of course, the more field experience he has. Teacher experience is very useful to know the similarities and differences of students (Rida, Dantes, \& Dantes, 2013).

Work period is a period of time or length of an employee in devoting himself to a company or organization. The working period in its implementation is physical and spiritual activities carried out by humans to achieve their goals or contain a certain masud. The working period is defined as the length of time a teacher is engaged in his work at an educational institution or school institution.

According to Rida et al. (2013) Broadly speaking, the tenure can be categorized into 3, namely: 1) New service period: <6 years, 2) Moderate work period: 6-10 years, 3) Long working period:> 10 year. The work period is calculated from the time the teacher is appointed to be a civil servant / non PNS as a teacher, so that the person concerned is nominated as a candidate for teacher certification through a decree stipulating the head of the district / city education office. For non PNS teachers, the period of service is calculated from the time the person is first appointed and is assigned to become a teacher in an education unit (Murwati, 2013).

The research conducted by Novitasari (2015) revealed that teacher tenure variables contributed $35.4 \%$ to teacher performance variables. It is known that there is a significant effect of working period and teacher education together on the performance of teachers at Sukabumi 10 Elementary School in Probolinggo City, so that the statistical decisions that can be taken are that there is a significant influence on the work period and teacher education on the performance of teachers in Sukabumi 10 Elementary School. In addition to educational qualifications and years of work, the school climate can also affect the performance of economic teachers. The problem is that there are still many teachers who have not carried out the tasks of learning and education in schools with professionals and lack of teaching performance that is good in carrying out their duties as teachers, one of which can be influenced by the school climate that is less supportive in developing a teacher's performance.

School climate is a situation or atmosphere that arises because of the relationship between the principal and the teacher, the teacher with the teacher, the relationship between students and the relationship between students in schools (Saggaf, Nasriyah, Salam, \& Wirawan, 2018; Salam, Akib, \& Daraba, 2018). The school climate can be shown from a variety of benefits that are useful in terms of openness and health of interpersonal relationships (Rivai \& Murni, 2010). 
60 Jurnal Ilmiah Ilmu Administrasi Publik: Jurnal Pemikiran dan Penelitian Administrasi Publik
Volume 9 Number 1, January - June 2019. Page 57-70

School climate is seen as an environmental quality that can influence the behavior of members who describe the personality of those who influence each other who have a large impact on organizational behavior. School climate is a social environment that survives during the education process.

School climate refers to the teacher's perception of the general school work environment, formal organization, informal organization, the personality of participants, and the organizational leadership that influences it. The climate of a series of internal characteristics that can distinguish one school from another and can affect the behavior of members in each concerned school (Wargocki \& Wyon, 2017). School is an effective school indicator that emphasizes the pleasant feeling from the school atmosphere. The obligation of schools is to create an internal environment as a pleasant, harmonious, and responsible environment, which contains several elements, namely: 1) High expectations of students, 2) Attitudes of effective teachers and 3) School order and discipline (Komariah \& Triatna, 2005).

The results of research conducted by Rahmawati (2011) have a positive and significant influence on the teaching school of the performance of vocational teachers in the City of Bandung. In addition, work motivation also has a positive and significant influence on the teaching performance of Vocational Teachers in Bandung City. Simultaneously, the school climate and work Motivation affects teaching performance of vocational teachers in the city of Bandung. The climate and work motivation are simultaneously simultaneous. While others are influenced by other variables.

The climate is how we treat each other. School that characterizes school norms, goals, values, interpersonal relationships, teaching and learning practices and organizational structure. Achieving school goals one of which depends on the teacher's carrying out functions as a teacher, starting from planning, implementing and evaluating learning.

The Vocational Schools in Makassar City have been well-identified in the Vocational Schools. Therefore, by not reducing the role and function of other factors, he chose the educational qualifications, years of service and school climate as the research variable. The three variables are to have an influence on improving the performance of economic teachers.

\section{METHOD}

This research is a type of expo-facto research, using a quantitative approach, namely research that presents data in the form of numbers and uses statistical analysis. The paradigm used in this study is a dual paradigm with three independent variables namely educational qualifications (X1), years of service (X2) and school climate (X3) on the performance of economic teachers $(\mathrm{Y})$. So here there are independent variables (variables that influence) and dependents (which are affected). The type of data used in this study is quantitative data, and this research was conducted to determine the effect of educational qualifications, years of service, and school climate on the performance of economic teachers in SMKs throughout Makassar.

The number of population (Population Number) in this study is all teachers of economic subjects. As for this study, the entire population will be observed, because the population size is taken as a whole, therefore this study uses the census method, which is the overall object of 
assessment in a certain period. The population in this study were economics teachers throughout the city of Makassar. The population was taken from all economic teachers at SMKN in the city of Makassar. In the context of this study, which includes economic teachers are accounting / finance teachers, business economics, entrepreneurship, and marketing. There are 9 SMKs in Makassar city that have economic teachers.

The sampling technique in this study used a census (saturated sample), because the population in the study was quite small. Saturated sampling technique (census) is a sampling technique if all members of the population are used as samples. There are 9 SMKs in Makassar city that have subjects and economic teachers. So that the sample used in this study were all economic teachers of Vocational High Schools in Makassar City totaling 70 people with 55 undergraduate education qualifications and 15 Masters.

The instrument used in this study was a questionnaire / questionnaire with a closed statement. Data collection for independent variables is done by giving questionnaires / questionnaires to students as respondents by giving a sign on each question category arranged based on the Likert scale with 5 points. Each respondent's answer will be given a score and the number of scores indicates the height or low of each measured variable. Five answers and weighted scores are scored, so that each variable is measured according to the interval scale.

The validation of the instrument in this study was carried out with content validity and construct validity and reliability testing. Content validity is done by asking for expert judgment expert assistance. While construct validity is done to test empirically the relationship between items and to determine groups of questions that determine each other as a factor / construct that is measured through the instrument using Product moment correlation. Test reliability is related to the confidence and consistency of the test results using the Cronbach Alpha technique. Descriptive and inferential analysis is used to analyze collected data using path analysis with the help of the SPSS for Windows 21 program.

\section{RESULT AND DISCUSSION}

The results of the normality test data with Kolomogorov-Smirnov in the Test of Normalty table are Sig. or the significance or probability value found in the Kolomogorov-Smirnov column, which is 0.681 greater than alpha or the set error rate $(>0.05)$. So it can be concluded that the analyzed data is normally distributed. The results of multicollinearity testing obtained did not occur multicollinearity because all $\mathrm{r}$ values between variables were less than 0.8 (X1 correlation to $\mathrm{X} 2=0.373, \mathrm{X} 1$ to $\mathrm{X} 3=0.200, \mathrm{X} 2$ to $\mathrm{X} 3=0.142$ ).

The results of testing heteroscedasticity with the Glejser test obtained a significance value for all independent variables greater than $0.05(\mathrm{X} 1=0.176, \mathrm{X} 2=0.678 \mathrm{X} 3=0.422)$ so it can be concluded that this study did not occur. Furthermore, the results of path analysis using multiple regression analysis can be seen in table 1 . 
62 Jurnal Ilmiah Ilmu Administrasi Publik: Jurnal Pemikiran dan Penelitian Administrasi Publik Volume 9 Number 1, January - June 2019. Page 57-70

Table 1.

Summary of Analysis Results

\begin{tabular}{cccccc}
\hline Hypothesis & $\begin{array}{c}\text { Value of T }\left(\mathbf{T}_{\text {count }}\right. \\
\text { and } \mathbf{T}_{\text {table }} \text { ) }\end{array}$ & Sig & $\begin{array}{c}\text { Direct } \\
\text { Influence }\end{array}$ & $\begin{array}{c}\text { Indirect } \\
\text { Effects }\end{array}$ & $\begin{array}{c}\text { Total } \\
\text { Influence }\end{array}$ \\
\hline X1 against X3 & $0,163>1,995$ & 0,035 & 0,021 & & \\
X2 against X3 & $1.175>1,995$ & 0,022 & 0,153 & & \\
X1 against Y & $1.367>1,995$ & 0,008 & 0,177 & & \\
X2 against Y & $0.418>1,995$ & 0,039 & 0,54 & & \\
X3 against Y & $0,808>1,995$ & 0,011 & 0.98 & & $0,175$. \\
X1 against Y through & & & & 0,149 & $0,203$. \\
X3 & & & & & \\
X2 against Y & & & & & \\
Through X3 & & & & & \\
\hline
\end{tabular}

\section{Direct influence of educational qualifications on the school climate on economic teachers}

Based on table 1, the results show that the significant value of X1 against X3 is less than 0.05 , which is $0.071 / 2=0.035$ and $\mathrm{T}_{\text {count }}>\mathrm{T}_{\text {table, }}$, so the $\mathrm{H} 1$ decision can be taken. This means that there is a significant direct effect of the school environment on learning motivation. The direct effect of $\mathrm{X} 1$ on $\mathrm{X} 3$ is 0.21 .

The results of the study showed that there was an effect of educational qualifications on the school climate in all Vocational Schools in Makassar at 0.021. In the results of this study there were only 0.021 or $2.1 \%$ of the direct influence of educational qualifications on the school climate, meaning that there were indirect effects on other variables outside of the variables studied. Even though the significance value is low, education qualifications are still needed to create a school climate full of inter-personnel communication, safe, secure and conducive.

The results of the research conducted by Pilly (2010) with the title Relationship between Teacher Education Levels, School Principal Development, and School Climate on Teacher Professionalism in West Halmahera District Middle School are known to have a significant relationship between teacher education, school principal and climate development individually and jointly on the professionalism of teachers in the West Halmahera District Middle School. The contribution of the level of teacher education to the professionalism of teachers in West Halmahera District Middle School is $17.3 \%$. The contribution of the school principal's relationship to the professionalism of teachers in West Halmahera District Public Middle School is $4.4 \%$. The contribution of the school climate relationship to the professionalism of teachers in West Halmahera District Public Middle School is $18.6 \%$. The contribution of the relationship between the level of teacher education, the guidance of the principal, and the school climate that is conducive to the professionalism of the teacher together. 


\section{Direct effects of years of service on the school climate on economic teachers}

Based on table 1, the results show that the significance value of $\mathrm{X} 2$ to $\mathrm{X} 3$ is less than 0.05 , which is $0.044 / 2=0.022$ and $\mathrm{T}_{\text {Count }}>\mathrm{T}$ table $\left(\mathrm{T}_{\text {Count }}=1.175, \mathrm{~T}_{\text {table }}=1.995\right)$. significant utilization of learning facilities for learning motivation and the magnitude of the direct influence is 0.153 .

Based on the results of the hypothesis test conducted, stating the direct effect of the working period variable on the school climate obtained the value of the structural equation coefficient of 0.153 or $15.3 \%$. This means that there is a significant direct effect on the working period on the school climate. This result shows an analysis that the working period is needed to achieve a conducive school climate.

Based on the results of research, teacher work experience is an important part of the process of developing his expertise. Within one year, at least 2-3 teachers attend training. Experience and training are obtained through a period of work. Through work experience consciously or unconsciously they learn, so that eventually they will have technical skills, as well as skills in facing work. The average teacher who has participated in the training will implement the knowledge gained so that it has a positive impact on students and other school personnel.

Through work experience and level of education possessed by the teacher, the teacher will be easier in completing every job that is charged so as to create a conducive school atmosphere. work experience, a teacher can guide younger teachers with experience that has been gained. Most teachers with a long working period will be easier to get along with old or new teachers and be able to control a conducive atmosphere with other teachers. The creation of a harmonious relationship will also affect the school climate.

Research conducted by Rahmawati (2014) with the title "the influence of school climate and work motivation on the performance of teaching vocational teachers in the city of Bandung. The school climate has a positive and significant influence on teacher teaching performance Simultaneously, the school climate and work motivation influence the teaching performance of vocational teachers in the city of Bandung. The conclusion of this study is the level of teaching performance of vocational teachers in the city of Bandung is influenced by variable school climate and work motivation simultaneously. While others are influenced by other variables.

\section{Direct influence of educational qualifications on the performance of economic teachers}

Based on the results of data analysis in table 1 that the significance value of $\mathrm{X} 1$ to $\mathrm{Y}$ is less than $0.050 .176 / 2=0.008$ and $\mathrm{T}_{\text {table }}=1.995$ and $\mathrm{T}_{\text {Count }}>\mathrm{T}$ table then $\mathrm{H} 1$ decisions can be taken accepted. This means that there is a significant direct effect of educational qualifications on the performance of economic teachers. The value of the direct effect of $\mathrm{X} 1$ on $\mathrm{Y}$ is 0.177 or $17.7 \%$.

These results can be seen the relationship of educational qualifications to performance through indicators in teacher performance, namely by the implementation of planning, evaluation, attendance, work commitment, and the ability to work together. Both in determining the level of education and planning in the teaching and learning process. And see indicators of educational qualifications, namely formal diplomas, education levels and relevance of majors. According to some teachers the qualifications of education greatly 
64 Jurnal Ilmiah Ilmu Administrasi Publik: Jurnal Pemikiran dan Penelitian Administrasi Publik Volume 9 Number 1, January - June 2019. Page 57-70

influence the knowledge and performance of teachers. To improve professionalism, performance and competence, teachers are required to continue their studies to the level of S2 I S3 and attend training.

According to Mangkunegara (2005) the level of education is a long-term process that uses systematic and organized procedures, in which managerial workforce learns conceptual and theoretical knowledge for general purposes. There is a positive relationship between teacher education qualifications and performance. For this reason, efforts to improve education for teachers will influence the implementation of their teaching duties. In other words, that the higher the teacher's education qualifications will allow they teacher to take responsibility for educating, guiding and teaching better, effectively and efficiently.

This is in line with Awe's research, with the title of the relationship between academic qualifications, competence, work motivation and the performance of elementary school (SD) teachers in Bajawa sub-district, Ngada district. 1) there is a positive and significant relationship between academic qualifications and teacher performance, 2) there is a positive and significant relationship between competence and teacher performance, 3 ) there is a positive and significant relationship between work motivation and teacher performance, 4) there is a positive relationship and significantly together between academic qualifications, competence, work motivation and teacher performance (Awe, Dantes, \& Lasmawan, 2014). The three factors of academic qualifications, competence and work motivation can be used as predictors of the level of tendency of performance of elementary school teachers in Bajawa sub-district, Ngada district.

\section{The direct effect of tenure on the performance of economic teachers}

Based on the results of data analysis in table 1 that the significance value of $\mathrm{X} 2$ against $\mathrm{Y}$ is less than 0.05 , which is $0.078 / 2=0.039$ and $\mathrm{T}_{\text {table }}=1.995$ and $\mathrm{T}_{\text {hitung }}>\mathrm{Ttable}$ then $\mathrm{H} 1$ decisions can be taken accepted. This means that there is a significant direct effect. The value of the direct effect of $\mathrm{X} 2$ on $\mathrm{Y}$ is 0.054 or $5.4 \%$.

These results indicate an analysis that the effect of years of work on teacher performance is quite closely related, because to become a professional teacher, education and training and special education and work experience are needed. The amount of experience is inseparable from the length of work that is owned by a teacher. By going through a long and long working period, it will be able to enrich the knowledge and experience of a teacher. So this is what can also determine the quality of a teacher. So it was concluded that the longer the working period of a teacher, the more teaching experience gained, so that with more teaching experience, teachers can easily and quickly solve problems faced, especially teaching problems, which shows that teacher performance is getting better. Work period or work experience is essentially a summary of someone's understanding of things experienced in teaching, socializing with school institutions and the environment outside the school, so that the things experienced by the teacher have been mastered.

The results of this study are reinforced by the research of Hasan R. (2017) with the title: Effect of tenure and teacher education on the performance of teachers at SDN Sukabumi 10 in Probolinggo. It is known that there is a significant effect on the performance of teachers in 
Sukabumi 10 Elementary School in Probolinggo City. It is known that there is a significant effect of working period and teacher education together on the performance of teachers at Sukabumi 10 Elementary School in Kota Probolinggo, there is a significant effect on the work period and teacher education on the performance of teachers at Sukabumi 10 Elementary School in Probolinggo City.

\section{The direct influence of the school climate on the performance of economic teachers}

Based on the results of data analysis in table 1 that the significance value of $\mathrm{X} 3$ against $\mathrm{Y}$ $0.022 / 2=0.011$ and $\mathrm{T}_{\text {table }}=1.995$. Data shows that there is a significant relationship between school climate and economic teacher performance of 0.98 or $9.8 \%$. A positive conducive school climate can affect productivity increases and encourage teacher reform. It is known that there is a positive and significant direct relationship between school climate and teacher performance.

Judging from school climate indicators that affect the effectiveness of the performance of the individuals in it. The school climate can also affect the morale of students and teachers, in the form of pride in their school, a sense of being in line with their school, and something not real called the spirit of schooling and of course a harmonious relationship between school personnel. An unfavorable school climate will create a teacher's performance is low and an unpleasant atmosphere among personnel in the school, so that the school's vision and mission is not carried out smoothly and the learning process is less or not achieved optimally and results in students' performance falling. Interpersonal and staff relations are less harmonious, and teachers are less involved in decision making at school.

A positive school climate shows a close relationship with one another in many ways that occur with mutual cooperation among them, all problems that are raised are resolved together through deliberation. The positive climate shows that activities run in harmony and in a peaceful, calm atmosphere that provides peace, comfort to the personnel in general and the teacher in particular

Similar research also occurs in research conducted by Yovitha (2012) with a thesis entitled Relationship of school climate, task load, achievement motivation, and teacher job satisfaction with the performance of elementary school teachers. The school climate, task load, achievement motivation, and job satisfaction have an effect on improving performance. The school climate accompanied by achievement motivation does not affect the increase in performance, but the task load accompanied by achievement motivation influences performance improvement. While the school climate accompanied by job satisfaction has an influence on performance, but the burden of work accompanied by job satisfaction has no effect on performance. Indirect relationship between school climate and performance through job satisfaction.

With the emergence of negative attitudes of students called ressentiment that comes from pressures or restrictions on student behavior and demands for adjustments to schools that are above the limit. This shows that the school climate influences student attitudes and behavior which in turn affects teacher performance.

Indirect influence of educational qualifications on the performance of economic teachers

Direct influence given $\mathrm{X} 1$ (educational qualifications) to $\mathrm{Y}$ (economic teacher performance) of 0.177 . While the indirect effect of $\mathrm{X} 1$ (educational qualifications) on $\mathrm{Y}$ 
66 Jurnal Ilmiah Ilmu Administrasi Publik: Jurnal Pemikiran dan Penelitian Administrasi Publik Volume 9 Number 1, January - June 2019. Page 57-70

(economic teacher performance) through $\mathrm{X} 3$ (school climate) is the multiplication of the Beta value of $\mathrm{X} 1$ variable against $\mathrm{X} 3$ with Beta $\mathrm{X} 3$ value of $\mathrm{Y}$ that is $=0.021 \times 0.098=0.0021$. So, the total influence given $\mathrm{X} 1$ to $\mathrm{Y}$ is the direct effect coupled with the indirect effect of $0.177+$ $0.0021=0.175$.

Based on the results of these calculations, it is known that the direct effect value of $\mathrm{X} 1$ on $\mathrm{Y}$ is 0.177 and the indirect effect is 0.0021 , which means that the value of direct influence is smaller than the value of indirect influence. It means that the value of indirect influence is smaller than the value of direct influence and the significance value of $\mathrm{X} 1$ to $\mathrm{X} 2$ and $\mathrm{X} 3$ to $\mathrm{Y}$ $<0.05$. This indicates that indirectly $\mathrm{X} 1$ to $\mathrm{Y}$ through $\mathrm{X} 3$ has a significant influence. So in this case reject $\mathrm{H} 0$ and accept $\mathrm{H} 1$.

From the research that has been done, the level of education shows a positive impact and is indicated by the indicator that having a diploma and relevant academic degree is proven to be able to have a positive impact on teacher performance. The level of education will have a greater influence on teacher performance, if the level of education is not only realized by the ownership of diplomas and academic degrees, but also be balanced with a high level of discipline and motivation as well as work professionalism and regular socialization in the school environment. The level of education should be accompanied by an increase in work performance, in the form of being a model teacher. Teacher performance is the output of the quality of human resources called teachers. Because performance includes three elements, namely the actor (teacher), the process (activity degree of teaching), and the results of the teaching and learning process.

The results of the study conducted by (Antoni, 2017) with the title "The effect of the school climate and teacher performance on the learning motivation of students of SMK Negeri 1 Bukit Kemuning". The research hypothesis is: (1) the school climate has a significant effect on student learning motivation, (2) teacher performance has a significant effect on student learning motivation, (3) the school climate and teacher performance together have a significant effect on student learning motivation. There is an influence of the school climate and teacher performance together.

This research was also conducted by Syaikhul Alim (2010) with the title "Effects of educational qualifications, training and participation in the profession on the competence of elementary school pie teachers in Pekalongan district". The results of the analysis show findings: (1) there is a significant effect of educational qualifications on the competence of PAI SD teachers in Kab. Pekalongan. (2) there is a significant influence from the participation of training on the competency of elementary school PAI teachers in Kab. Pekalongan. (3) there is a significant effect of attitudes on the profession on the competence of elementary school PAI teachers in Kab. Pekalongan. (4) there is a significant influence of educational qualifications, the participation of training and attitudes on the profession simultaneously on the competence of elementary school PAI teachers in Kab. Pekalongan.

The indirect effect of working period on the performance of economic teachers at the Vocational Schools in Makassar through the school climate. 
Based on the results of the study, it shows that there is a direct influence on the working period on the performance of economic teachers in SMKs throughout the city of Makassar. These results indicate that the direct effect of X2 (years of service) on Y (economic teacher performance) is 0.054 , while the indirect effect of $\mathrm{X} 2$ (years of service) on $\mathrm{Y}$ (economic teacher performance) through X3 (school climate) is the multiplication of Beta values X2 against X3 with a Beta X3 value of $\mathrm{Y}$ which is $0.153 \times 0.098=0.149$. Then the total effect given by $\mathrm{X} 2$ on $\mathrm{Y}$ is the direct effect coupled with the indirect effect of $0.054+0.149=0.203$.

Based on the results of these calculations, it is known that the direct effect of $\mathrm{X} 2$ on $\mathrm{Y}$ is 0.054 and the indirect effect is 0.203 , which means that the value of direct influence is smaller than the value of indirect influence. This shows that indirectly X2 to $\mathrm{Y}$ through $\mathrm{X} 3$ has a significant effect so in this case the hypothesis rejects Ho and accepts H1.

Based on the hypothetical model, mathematical equations with endogenous variables X3 were formulated as follows:

$\mathrm{X} 3=0.021 \mathrm{X} 1+0.153 \mathrm{X} 2-0.098 \mathrm{X} 3+0.944 \varepsilon 3$

The working period has a positive and significant contribution to the increase in teacher performance and professionalism, which means that the length of work of teachers in SMKs in the city of Makassar is used to make a positive contribution to the teacher's professionalism. The higher the working period means the better the teacher's professionalism and the lower the working period, the lower the teacher's performance and professionalism. If in teaching the teacher to find new things, and new things he understands, then the teacher will get a lot of additional knowledge and skills about his field of work. This is because knowledge and experience can contribute to the mastery of classroom management skills, because with adequate education and supported by a long working period, it allows teachers to know more and understand various aspects of the implementation of teacher assignments that are directly related to improving student achievement and achievement. the teacher himself.

This was reinforced by a study by Rida et al. (2013) with the title of the relationship between work motivation, years of service, and teacher welfare with the professionalism of teachers of Public Elementary Schools in Grabag District, Magelang Regency. The results of this study are (1) There is a variable positive relation

nship between Teacher Motivation and Teacher Professionalism. (2) There is a positive variable relationship The work period of the teacher with Teacher Professionalism. (3) There is a positive relationship between variables Work Motivation, Work Period, and Teacher Welfare with Teacher Professionalism.

\section{CONCLUSION}

Based on the results of the research and discussion, it can be concluded that (1) There is a significant direct effect of educational qualifications on the school climate on economic teachers in SMKs throughout Makassar City. (2) There is a significant direct effect on the working period on the school climate for economic teachers in SMKs throughout Makassar City. (3) There is a direct influence of educational qualifications on the performance of economic teachers in SMKs throughout Makassar City. (4) There is a direct influence on the working period on the performance of economic teachers in SMKs throughout Makassar City. (5) There 
68 Jurnal Ilmiah Ilmu Administrasi Publik: Jurnal Pemikiran dan Penelitian Administrasi Publik Volume 9 Number 1, January - June 2019. Page 57-70

is a direct influence of the school climate on the performance of economic teachers in SMKs throughout Makassar City. (6) There is an indirect influence of the qualification of education through School Climate on the performance of Economic teachers in SMKs throughout Makassar City. (7) There is an indirect effect of the Working Period through School Climate on the performance of Economic teachers in SMKs throughout Makassar City.

\section{REFERENCES}

Akib, H., \& Salam, R. (2016). Analisis Kualitas Pelayanan Publik Berbasis Importance Performance Analysis (IPA) pada Kecamatan Kota Makassar. Jurnal Ilmiah Scientific Pinisi, 2(April 2016), 16-20.

Antoni, A. (2017). Pengaruh iklim sekolah dan kinerja guru terhadap motivasi belajar siswa SMK Negeri 1 BukitKemuning Kecamatan BukitKemuning Kabupaten Lampung Utara. UIN Raden Intan Lampung.

Awe, E. Y., Dantes, N., \& Lasmawan, I. W. (2014). Hubungan Antara kualifikasi akademik, kompetensi, motivasi kerja dengan kinerja guru sekolah dasar (SD) di Kecamatan Bajawa, Kabupaten Ngada. PENDASI: Jurnal Pendidikan Dasar Indonesia, 4(1).

Dharma, S., \& Akib, H. (2005). The Influence of Job Satisfaction on Work Performance: a Theoretical Approach. Manajemen USAHAWAN Indonesia, (2), 30-33.

Hariyono, U. S., Sopyan, Y., Akib, H., Haris, H., Paraga, S., \& Astuti, A. (2019). The Effectiveness of the Performance of Civil Servants in the Integrated Service Office in Gowa Regency. 1st International Conference on Advanced Multidisciplinary Research (ICAMR 2018). Atlantis Press.

Hasibuan, M. (2002). Manajemen Sumber Daya Manusia. Edisi Revisi. Cetakan keenam. Jakarta: PT. Bumi Aksara.

Khunsoonthornkit, A., \& Panjakajornsak, V. (2018). Structural equation model to assess the impact of learning organization and commitment on the performance of research organizations. Kasetsart Journal of Social Sciences, 39(3), 457-462. https://doi.org/https://doi.org/10.1016/j.kjss.2018.07.003

Komariah, A., \& Triatna, C. (2005). Visionary leadership menuju sekolah efektif. Jakarta: Bumi Aksara.

Li, S. K., \& He, X. (2019). The impacts of marketization and subsidies on the treatment quality performance of the Chinese hospitals sector. China Economic Review, 54, 41-50. https://doi.org/https://doi.org/10.1016/j.chieco.2018.10.007

Mahlamäki, T., Rintamäki, T., \& Rajah, E. (2018). The role of personality and motivation on key account manager job performance. Industrial Marketing Management. https://doi.org/https://doi.org/10.1016/j.indmarman.2018.11.013 
Murwati, H. (2013). Pengaruh sertifikasi profesi guru terhadap motivasi kerja dan kinerja guru di smk negeri se-Surakarta. Jurnal Pendidikan Bisnis Dan Ekonomi (BISE), 1(1), 1-10.

Muslich, M. (2007). Sertifikasi guru menuju profesionalisme pendidik. Jakarta: Bumi Aksara.

Novitasari, N. (2015). Pengaruh Masa Kerja dan Tingkat Pendidikan Guru Terhadap Persepsi Guru Di SMA Negeri se-Sukoharjo Mengenai Kurikulum 2013 Tahun Ajaran 2014/2015. Universitas Muhammadiyah Surakarta.

Pilly, A. R. (2010). Hubungan Tingkat Pendidikan Guru, Pembinaan Oleh Kepala Sekolah, dan Iklim Sekolah terhadap Profesioanlisme Guru di SMP Negeri Kabupaten Halmahera Barat. Tesis. Yogyakarta: Program Pasca Sarjana Universitas Negeri Yogyakarta.

Primaraharjo, B., \& Handoko, J. (2011). Pengaruh Kode Etik Profesi Akuntan Publik Terhadap Kualitas Audit Auditor Independen di Surabaya. Jurnal Akuntansi Kontemporer, 3(1).

Rahmawati, I. (2011). Pengaruh Iklim Sekolah Dan Motivasi Kerja Terhadap Kinerja Mengajar Guru Smk Di Kota Bandung. Jurnal Administrasi Pendidikan, 13(1), 115-122.

Rida, M., Dantes, N., \& Dantes, K. R. (2013). Hubungan Motivasi Kerja, Masa Kerja Dan Kesejahteraan Guru Terhadap Profesionalisme Guru Sekolah Dasar Negeri Di Gugus II Kecamatan Sukasada. PENDASI: Jurnal Pendidikan Dasar Indonesia, 3(1).

Saad, G., Cleveland, M., \& Ho, L. (2015). Individualism-collectivism and the quantity versus quality dimensions of individual and group creative performance. Journal of Business Research, 68(3), 578-586. https://doi.org/https://doi.org/10.1016/j.jbusres.2014.09.004

Saggaf, M. S., Aras, M., Akib, H., Salam, R., Baharuddin, A., \& Kasmita, M. (2018). The Quality Analysis of Academic Services Based on Importance Performance Analysis (IPA).

Saggaf, M. S., Nasriyah, N., Salam, R., \& Wirawan, H. (2018). The Influence of Teacher's Pedagogic Competence on Learning Motivation of Student of Office Administration Expertise Package.

Saggaf, M. S., \& Salam, R. (2017). Examining Academic Service using Importance Performance Analysis (IPA).

Salam, R., Akib, H., \& Daraba, D. (2018). Utilization of Learning Media In Motivating Student Learning. 1st International Conference on Social Sciences (ICSS 2018). Atlantis Press.

Singh, V., \& Singh, M. (2018). A burnout model of job crafting: Multiple mediator effects on job performance. IIMB Management Review, 30(4), 305-315. https://doi.org/https://doi.org/10.1016/j.iimb.2018.05.001

Song, Y. (2019). Sorting, school performance and quality: Evidence from China. Journal of Comparative Economics, 47(1), 238-261. https://doi.org/https://doi.org/10.1016/j.jce.2018.11.004

Sui, W., Smith, S. T., Fagan, M. J., Rollo, S., \& Prapavessis, H. (2019). The effects of sedentary behaviour interventions on work-related productivity and performance outcomes in real and simulated office work: A systematic review. Applied Ergonomics, 75, 27-73. 
70 Jurnal Ilmiah Ilmu Administrasi Publik: Jurnal Pemikiran dan Penelitian Administrasi Publik Volume 9 Number 1, January - June 2019. Page 57-70

https://doi.org/https://doi.org/10.1016/j.apergo.2018.09.002

Syaikhul Alim, M. (2010). Pengaruh Kualifikasi Pendidikan, Keikutsertaan Diklat dan Sikap pada Profesi terhadap Kompetensi Guru PAI SD di Kabupaten Pekalongan. IAIN Walisongo.

Wahyuni, A. A. (2016). Pengaruh Pendidikan dan Pelatihan (Diklat), Masa kerja, dan Sikap kerja terhadap Kinerja guru Di MTs Negeri 410 Tanete. Universitas Negeri Makassar.

Wargocki, P., \& Wyon, D. P. (2017). Ten questions concerning thermal and indoor air quality effects on the performance of office work and schoolwork. Building and Environment, 112, 359-366. https://doi.org/https://doi.org/10.1016/j.buildenv.2016.11.020 